\title{
ANALISIS PENERAPAN TUNNELING INCENTIVE \\ DAN MEKANISME BONUS TERHADAP \\ PRAKTIK PENGHINDARAN PAJAK
}

\author{
Dinda Fali Rifan
}

dinda.falirifan@radenintan.ac.id

Universitas Islam Negeri Raden Intan Lampung, Indonesia

\section{FIDUSIA}

Jurnal Ilmiah Keuangan dan Perbankan

ISSN Cetak : 2621-2439

ISSN Online : 2621-2447

\section{ABSTRAK}

Penelitian ini bertujuan untuk menganalisis penerapan tunneling incentive dan mekanisme bonus terhadap praktik penghindaran pajak. Penelitian ini menggunakan pendekatan kualitatif dengan teknik pengumpulan data melalui studi pustaka. Hasil penelitian menunjukkan perusahaan multinasional sebagai perusahaan yang memiliki hubungan dengan pihak berelasi akan memiliki kemudahan dalam melakukan tunneling incentive pada transaksi transfer pricing. Kondisi ini merupakan upaya penghindaran pajak yaitu melalui manipulasi beban pajak. Selain itu, faktor non-pajak yang menjadi motif praktik penghindaran pajak adalah mekanisme bonus. Penerapan mekanisme bonus dapat mengindikasi perusahaan untuk melakukan praktik penghindaran pajak karena direksi dan manajemen memanipulasi laba perusahaan dengan tujuan memperoleh bonus. 


\section{Pendahuluan}

\subsection{Latar Belakang}

Pajak merupakan sumber pendapatan negara yang berpotensi di Indonesia.

Penerimaan pajak di Indonesia setiap tahunnya terus meningkat. Pajak merupakan salah satu sumber pendapatan negara yang berasal dari rakyat. Dengan adanya penerimaan pajak, pemerintah dapat melakukan program-program dan pembangunan yang menjadi fasilitas publik untuk dinikmati oleh seluruh lapisan masyarakat. Namun jika dilihat dari dua sisi yaitu dari sisi pemerintah dan para pengusaha memiliki dua persepsi yang berbeda. Jika para pengusaha berusaha untuk membayarkan pajak seminimal mungkin, maka pemerintah berusaha untuk mendapatkan penerimaan pajak semaksimal mungkin. Menurut Saifudin (2018), sebagai perusahaan yang berorientasi laba maka perusahaan akan berusaha untuk mendapatkan keuntungan yang maksimal termasuk dengan efisiensi biaya.

Perusahaan tidak mendapatkan keuntungan secara langsung atas pembayaran pajak yang telah dilakukan sehingga hal ini memicu para pengusaha untuk melakukan penghindaran pajak atas kewajiban pajak yang seharusnya dibayar yaitu dengan berbagai cara agar pajak yang dibayarkan kecil. Penghindaran pajak atau yang dikenal dengan Tax Avoidance adalah menggunakan celah kesempatan dari perundang-undangan perpajakan yang masih abu-abu. Jika dilihat dari sisi pemerintah, tentunya hal ini bertentangan, pemerintah akan selalu berupaya agar penerimaan pajak yang diterima sesuai dengan penerimaan pajak yang seharusnya diterima. Pemerintah berupaya untuk mendorong perusahaan patuh terhadap kewajiban pembayaran pajaknya karena perusahaan akan tidak secara langsung menerima keuntungan dari pembayaran pajak tersebut melainkan secara tidak langsung. Contohnya adalah perusahaan yang taat akan pembayaran pajak akan mendapatkan reputasi yang baik di mata masyarakat. Menurut Agusti dalam Irawan, Havid, dan Yusriati (2017), salah satu kendala dalam rangka optimalisasi penerimaan pajak adalah dengan adanya penghindaran pajak (tax avoidance).

Menurut Pohan (2013), Penghindaran pajak atau sering disebut dengan Tax Avoidance adalah upaya mengefisiensikan beban pajak dengan cara menghindari pengenaan pajak dengan mengarahkannya pada transaksi yang bukan objek pajak. Beberapa cara yang dapat dilakukan dalam praktik penghindaran pajak adalah melalui adanya tunneling incentive dan mekanisme bonus yang dilakukan oleh perusahaan. Tunneling incentive merupakan perilaku yang dilakukan oleh pihak manajemen atau pemegang saham mayoritas untuk mentransfer aset atau keuntungan perusahaan kepada mereka sendiri demi kepentingan pribadi namun dibebankan kepada para pemegang saham minoritas. Selain itu, dari faktor non pajak yang dapat menjadi motif perusahaan melakukan penghindaran pajak adalah dengan adanya mekanisme bonus (Saifudin, 2018). Penerapan mekanisme bonus di dalam suatu perusahaan dapat mengindikasi terjadinya praktik penghindaran pajak yang dilakukan oleh pihak manajemen maupun para pemegang saham mayoritas. Hal ini dikarenakan pihak manajemen akan terus berupaya untuk meningkatkan kinerja perusahaan dengan tujuan dapat memperoleh bonus maupun reward. 
Berdasarkan latar belakang dan uraian di atas, maka penelitian ini akan membahas tentang "Analisis Penerapan Tunneling Incentive dan Mekanisme Bonus Terhadap Praktik Penghindaran Pajak".

\subsection{Permasalahan Penelitian}

Berdasarkan uraian di atas, maka pokok-pokok permasalahan yang akan dibahas dalam penelitian ini adalah :

1. Bagaimana penerapan dari tunneling incentive terhadap praktik penghindaran pajak?

2. Bagaimana penerapan dari mekanisme bonus terhadap praktik penghindaran pajak?

\subsection{Tujuan Penelitian}

Berdasarkan perumusan masalah yang telah diuraikan di atas, maka tujuan dari penelitian ini adalah :

1. Untuk menganalisis penerapan dari tunneling incentive terhadap praktik penghindaran pajak.

2. Untuk menganalisis penerapan dari mekanisme bonus terhadap praktik penghindaran pajak.

\section{Metode}

\subsection{Metode Penelitian yang Digunakan}

Metode penelitian yang digunakan di dalam penelitian ini adalah menggunakan metode penelitian kualitatif. Penelitian ini menggunakan metode kualitatif dikarenakan:

1. Penelitian bersifat naturalistik karena mempelajari objek secara apa adanya tanpa bermaksud melakukan manipulasi dan intervensi.

2. Analisis dilakukan secara induktif dengan cara mendalami data untuk menemukan dimensi dan hubungan yang penting.

3. Pengumpulan data lebih bersifat longgar, fleksibel, dan dapat berubah sewaktu-waktu tergantung kebutuhan.

4. Data-data yang tersedia bersifat kualitatif dan kutipan langsung berupa ketentuanketentuan dan aturan-aturan.

Di dalam penelitian ini, teknik pengumpulan data akan dilakukan melalui studi pustaka atas bahan-bahan literatur serta peraturan terkait. Hasil dari literature review akan dianalisis sehingga dapat menjawab pertanyaan penelitian. Oleh karena itu, pendekatan kualitatif dipilih untuk digunakan pada penelitian ini. Penelitian ini dilakukan dengan menggunakan pendekatan kualitatif dengan tujuan untuk memperoleh gambaran secara mendalam mengenai objek penelitian yaitu mengenai penerapan tunneling incentive dan mekanisme bonus terhadap praktik penghindaran pajak. 


\subsection{Jenis Penelitian}

Jenis penelitian yang digunakan pada penelitian ini adalah penelitian deskriptif. Pemilihan jenis ini didasarkan pada pertimbangan bahwa penelitian ini akan menggambarkan dan menganalisis mengenai penerapan tunneling incentive dan mekanisme bonus terhadap praktik penghindaran pajak. Di dalam penelitian ini akan diuraikan pengetahuan dan informasi seputar penerapan dari adanya tunneling incentive dan mekanisme bonus terhadap praktik penghindaran pajak yang dilakukan perusahaan khususnya perusahaan multinasional. Penelitian ini tidak hanya menggambarkan atau menjelaskan mengenai data yang diperoleh tetapi juga menganalisis dan menginterpretasikan data tersebut.

\subsection{Metode Pengumpulan Data}

Pengumpulan data yang digunakan di dalam penelitian ini dilakukan melalui studi kepustakaan dari berbagai referensi, seperti buku text, jurnal, artikel, dan sumber-sumber tertulis lainnya mengenai tunneling incentive, mekanisme bonus, dan penghindaran pajak.

\section{Hasil dan Pembahasan}

Hubungan antara pihak manajemen perusahaan (agent) dengan pihak pemegang saham (principal) dijelaskan di dalam teori agensi. Pihak manajemen perusahaan (agent) memiliki wewenang untuk mengelola sumber daya yang dimiliki oleh perusahaan. Hal ini dapat menimbulkan asymmetric information informasi antara pihak manajemen perusahaan dengan pemegang saham dikarenakan pihak manajemen perusahaan memiliki informasi yang lebih banyak dibandingkan pemegang saham atas wewenang yang diberikan oleh pihak pemegang saham dalam mengelola sumber daya perusahaan.

Menurut Suandy dalam Saifudin (2018) upaya perusahaan dalam meminimalkan beban pajak yang harus dibayar oleh perusahaan dapat dilakukan melalui manajemen pajak. Manajemen pajak dapat dilakukan dengan perencanaan pajak dengan cara meminimalkan pajak sedemikian rupa sehingga utang pajak berada pada posisi seminimal mungkin dan hal tersebut dilegalkan oleh pemerintah. Penghindaran pajak dilakukan untuk dapat meminimalkan beban pajak yang akan dibayarkan oleh perusahaan dengan cara mencari celah-celah ketentuan perundangan perpajakan yang riil yang dapat diterima oleh pihak fiskus dan penghematan pajak dengan memperkecil utang pajak penghasilan (Saifudin, 2018).

Berdasarkan teori agensi, konflik agensi dapat terjadi antara pihak pemegang saham mayoritas dengan pihak pemegang saham minoritas. Konflik ini dapat terjadi dikarenakan pihak pemegang saham mayoritas memaksakan semua keinginannya kepada pihak manajer untuk kepentingan pribadi pemegang saham mayoritas. Oleh karena itu, perusahaan dapat dengan mudah melakukan tindakan-tindakan negatif seperti melakukan penghindaran pajak. Upaya yang dilakukan adalah seperti memindahkan aset atau laba yang dimiliki oleh perusahaan, sehingga laba yang dihasilkan perusahaan menjadi lebih rendah. Proses pemindahan aset atau laba yang dihasilkan tersebut akan menurunkan keuntungan yang akan diperoleh pihak pemegang saham minoritas, 
dampaknya adalah para pemegang saham minoritas mengalami penurunan kesejahteraan yang diberikan perusahaan. Praktik memindahkan aset atau laba yang dilakukan oleh manajer akibat adanya dorongan dari pihak pemegang saham mayoritas merupakan satu pemicu utama terjadinya transfer pricing. Tindakan tunneling incentive melalui upaya pemindahan tersebut, akan mendorong pemegang saham mayoritas untuk mendapatkan keuntungan lebih sehingga pemegang saham mayoritas melakukan tindakan transfer pricing (Jafri dan Elia, 2018).

Menurut Anthony et al dalam Kurniawan, Bayu dan Rinandita (2018), Tunneling merupakan pemindahan harta perusahaan dari anak usaha pada satu negara ke anak usaha atau induk usaha di negara lainnya, atau dari perusahaan ke pemegang saham mayoritas untuk tujuan memperkaya pemegang saham mayoritas. Praktik dari tunneling incentive antara lain tidak membagikan dividen, menjual aset perusahaan pada pemegang saham mayoritas atau perusahaan yang dikuasai oleh pemegang saham mayoritas dengan harga lebih murah dibandingkan harga seharusya, posisi kunci perusahaan diduduki oleh pemegang saham mayoritas, sehingga proses tunneling bisa lebih mudah dilakukan (Laporta pada Kurniawan, Bayu dan Rinandita, 2018). Tunneling incentive merupakan suatu perilaku dari pemegang saham mayoritas yang mentransfer aset dan laba perusahaan demi keuntungan para pemegang saham mayoritas, namun pemegang saham minoritas ikut menanggung biaya yang para pemegang saham mayoritas bebankan (Hartati, Desmiyawati, dan Julita, 2015).

Perusahaan multinasional sebagai perusahaan yang memiliki hubungan dengan pihak berelasi akan memiliki kemudahan dalam melakukan tunneling incentive. Hal ini disebabkan akibat adanya kemungkinan untuk memindahkan aset atau laba yang dihasilkan oleh perusahaan sehingga laba perusahaan menjadi tampak lebih rendah. Kondisi ini merupakan upaya dalam melakukan penghindaran pajak yaitu melalui manipulasi beban pajak yang dibayarkan oleh perusahaan. Apabila pemgang saham memiliki kontrol yang besar dalam suatu perusahaan, maka tindakan perusahaan untuk melakukan transaksi dengan pihak berelasi dapat digunakan untuk mengalihkan aset dan laba perusahaan keluar dari perusahaan melalui penentuan harga yang tidak wajar untuk kepentingan pemegang saham mayoritas dibandingkan membagi dividennya kepada para pemegang saham minoritas (Jafri dan Elia, 2018). Hal ini mengakibatkan kerugian bagi pemegang saham minoritas karena harus menanggung biaya yang dibebankan oleh pemegang saham mayoritas demi keuntungan pemegang saham mayoritas saja. Upaya ini dilakukan hanya karena motif untuk melakukan penghindaran pajak.

Praktik penghindaran pajak sering dilakukan oleh perusahaan multinasional yang menginginkan laba tinggi. Keputusan yang diambil untuk melakukan penghindaran pajak dipengaruhi oleh faktor non-pajak juga yaitu mekanisme bonus (Saifudin, 2018). Pemberian bonus merupakan salah satu motivasi yang dilakukan untuk memperoleh laba yang tinggi tersebut. Dengan adanya mekanisme bonus ini akan mendorong pihak manajemen perusahaan atau direksi untuk dapat memperoleh bonus dengan meningkatkan kinerja perusahaan yaitu dengan cara menaikkan laba perusahaan setiap tahunnya, namun dengan tetap meminimalisir beban pajak yang harus dibayar oleh perusahaan. 
Mekanisme bonus merupakan imbalan yang diberikan oleh pemilik perusahaan kepada manajer karena memenuhi sasaran kinerja perusahaan, seorang manajer mungkin memperoleh bonus berdasarkan laba bersih, atau menurut target kenaikan laba bersih (Hansen dan Mowen, 2005). Mekanisme bonus yang diberikan oleh perusahaan adalah dalam rangka memberikan penghargaan (reward) kepada direksi atau manajer dengan tujuan untuk meningkatkan laba perusahaan. Mekanisme bonus di dalam strategi atau motif perhitungan dalam akuntansi ditujukkan untuk direksi atau manajemen sebagai penghargaan dilihat dari laba perusahaan. Oleh sebab itu, direksi atau manajemen akan selalu berupaya untuk meningkatkan laba perusahaan setiap tahunnya dengan tujuan dapat memperoleh bonus. Menurut Refgia dalam Rachmat (2019), mekanisme bonus berdasarkan laba merupakan cara yang paling sering digunakan oleh perusahaan untuk memberikan penghargaan kepada direksi atau manajer. Hal ini menyebabkan direksi atau manajer dapat memanipulasi laba untuk memaksimalkan penerimaan bonus, jika mekanisme bonus dilihat berdasarkan tingkat laba.

\section{Kesimpulan}

Berdasarkan hasil analisis yang telah dilakukan, maka dapat ditarik kesimpulan yaitu perusahaan multinasional sebagai perusahaan yang memiliki hubungan dengan pihak berelasi akan memiliki kemudahan dalam melakukan tunneling incentive. Praktik memindahkan aset atau laba yang dilakukan oleh manajer akibat adanya dorongan dari pihak pemegang saham mayoritas merupakan satu pemicu utama terjadinya transfer pricing. Kondisi ini merupakan upaya dalam melakukan penghindaran pajak yaitu melalui manipulasi beban pajak yang dibayarkan oleh perusahaan. Selain itu faktor non-pajak yang menjadi motif praktik penghindaran pajak adalah adanya mekanisme bonus. Mekanisme bonus dapat mengindikasi perusahaan untuk melakukan praktik penghindaran pajak karena direksi dan manajemen memanipulasi laba perusahaan dengan tujuan memperoleh bonus. Hal ini disebabkan mekanisme bonus berdasarkan tingkat laba yang dihasilkan oleh perusahaan. 


\section{DAFTAR PUSTAKA}

Hansen dan Mowen. 2005. “Management Accounting”. Buku 2 Edisi ke 7. Jakarta: Salemba Empat. Hartati, Winda. Desmiyawati. Julita. 2015. "Tax Minimization, Tunneling Incentive dan Mekanisme Bonus terhadap Keputusan Transfer Pricing seluruh Perusahaan yang Listing di Bursa Efek Indonesia “.Simposium Nasional Akuntansi 18 Universitas Sumatera Utara, Medan 16-19 September 2015.

Irawan, Yanuar. Havid Sularso. Yusriati Nur Farida. 2017. “Analisis atas Penghindaran Pajak (Tax Avoidance) pada Perusahaan Property dan Real Estate di Indonesia”. Sustainable Competitive Advantage-7 (SCA-7) Fakultas Ekonomi dan Bisnis Universitas Soedirman.

Jafri, Hasan Effendi dan Elia Mustikasari. 2018. "Pengaruh Perencanaan Pajak, Tunneling Incentive dan Aset Tidak Berwujud terhadap Perilaku Transfer Pricing pada Perusahaan Manufaktur yang Memiliki Hubungan Istimewa yang Terdaftar di Bursa Efek Indonesia Periode 20142016”. Berkala Akuntansi dan Keuangan Indonesia, Vol. 03, No. 02; 63-77.

Kurniawan, Muhammad Sani. Bayu Prabowo Sutjiatmo. Rinandita Wikansari. 2018. "Pengaruh Pajak dan Tunneling Incentive terhadap Tindakan Transfer Pricing pada Perusahaan Manufaktur yang Terdaftar di Bursa Efek Indonesia (BEI)”. Seminar Nasional Pakar ke 1, Buku 2.

Ngadiman dan Christiany Puspitasari. 2014. "Pengaruh Leverage, Kepemilikan Institusional, Dan Ukuran Perusahaan Terhadap Penghindaran Pajak (Tax Avoidance) Pada Perusahaan Sektor Manufaktur Yang Terdaftar Di Bursa Efek Indonesia 2010-2012 “. Jurnal Akuntansi, Vol. XVIII, No. 03; 408-421.

Pohan, Chairil. A. 2013. "Manajemen Perpajakan”. Jakarta: PT. Gramedia Pustaka Utama.

Pradipta, Dyah Hayu dan Supriyadi. 2015. "Pengaruh Corporate Social Responsibility (CSR), Profitabilitas, Leverage, dan Komisaris Independen Terhadap Praktik Penghindaran Pajak”. Simposium Nasional Akuntansi 18 Universitas Sumatera Utara, Medan 16-19 September 2015.

Rachmat, Radhi Abdul Halim. 2019. "Pajak, Mekanisme Bonus, dan Transfer Pricing”. Jurnal Pendidikan Akuntansi dan Keuangan, Vol. 07, No. 01; 21-30.

Saifudin, Luky Septiani Putri. 2018. "Determinasi Pajak, Mekanisme Bonus, dan Tunneling Incentive terhadap Keputusan Transfer Pricing pada Emiten BEI". Jurnal AGREGAT, Vol. 02, No. 01; 32-43. 